\title{
Jurist-Diction
}

Volume 4 No. 2, Maret 202

\section{Kecelakaan Kerja yang Dialami Pekerja yang Sedang Dalam Keadaan Work From Home}

\author{
Valerieo Ezra Hutagalung \\ valerieoezra29071999@gmail.com \\ Universitas Airlangga
}

\begin{abstract}
How to cite:
Valerieo Ezra Hutagalung,

'Kecelakaan Kerja yang

Dialami Pekerja yang Sedang Dalam Keadaan Work From Home' (2021) Vol. 4 No. 2

Jurist-Diction.
\end{abstract}

Histori artikel:

Submit 10 Januari 2021;

Diterima 18 Februari 2021;

Diterbitkan 1 Maret 2021.

DOI:

10.20473/jd.v4i2.25789

p-ISSN: 2721-8392

e-ISSN: $2655-8297$

\section{Abstract}

Workers' houses are not intended for use as a workplace. However, because of the COVID-19 pandemic in Indonesia, workers have been forced to Work From Home in their homes. To find about workers' legal protection against occupational accidents in the Work From Home system, it is deemed necessary to analyse the legal interpretation of a house as a workplace and as a work environment. Doing this will clarify the legal protection for workers who are in the system of Work From Home. There are two parties who are responsible for occupational accidents committed by workers who are currently working from home, namely employers and BPJS Ketenagakerjaan. Employers are responsible for preventing occupational accidents by implementing Occupational Safety and Health (K3) and BPJS Ketenagakerjaan responsible for work accidents through the Work Accident Security (JKK) program.

Keywords: Occupational Accident; Work From Home; Responsibility.

\section{Abstrak}

Rumah milik pekerja bukan merupakan tempat kerja yang digunakan oleh pekerja untuk melakukan pekerjaan, tetapi sejak adanya pandemi COVID-19 di Indonesia, pekerja terpaksa untuk Work From Home. Berkaitan dengan perlindungan hukum pekerja terhadap kecelakaan kerja hanya berlaku di tempat kerja yang juga termasuk dalam ruang lingkup lingkungan kerja, sehingga perlu dilakukan penafsiran hukum bahwa rumah dalam keadaan Work From Home sebagai tempat kerja yang juga termasuk lingkungan kerja supaya terdapat perlindungan hukum bagi pekerja yang dalam keadaan Work From Home. Ada dua pihak yang bertanggung jawab terhadap kecelakaan kerja yang dialami oleh pekerja yang sedang dalam keadaan Work From Home yaitu pemberi kerja dan BPJS Ketenagakerjaan. Pemberi kerja bertanggung jawab dalam hal pencegahan terjadinya kecelakaan kerja dengan menerapkan Keselamatan dan Kesehatan Kerja (K3) dan BPJS Ketenagakerjaan bertanggung jawab apabila telah terjadinya kecelakaan kerja melalui program Jaminan Kecelakaan Kerja (JKK).

Kata Kunci: Kecelakaan Kerja; Work From Home; Tanggung Jawab. 


\section{Pendahuluan}

Manusia merupakan makhluk ciptaan Tuhan yang dianugerahi sebuah akal pikiran dan kemampuan yang berbeda-beda dari setiap individu. Untuk mempertahankan kelangsungan hidupnya manusia membutuhkan sesuatu yang disebut kebutuhan pokok (primer) yang terdiri dari sandang, pangan dan papan. Untuk dapat membeli kebutuhan pokok tersebut dibutuhkan suatu benda yang memiliki fungsi sebagai alat pembayaran yang sah bernama yaitu uang.

Banyak cara untuk mendapatkan uang salah satunya yang dipilih oleh manusia adalah dengan mendapatkan suatu pekerjaan, karena dengan bekerja manusia akan mendapatkan upah atau dalam bentuk lain yang dapat digunakan untuk mempertahankan kelangsungan hidupnya. Bekerja itu sendiri mempunyai berbagai macam makna yaitu bekerja untuk diri sendiri dan bekerja dalam arti adanya hubungan kerja. ${ }^{1}$ Pekerjaan yang dilakukan untuk diri sendiri orang itu tidak diatur dalam hukum perburuhan karena tidak terdapat unsur hubungan kerja antara majikan dan tenaga kerja, dan juga tidak terdapat unsur pemberian upah. Kedua yaitu bekerja dalam arti adanya hubungan kerja, tenaga kerja mendapatkan upah atau bentuk lainnya atas jerih payah untuk menggunakan kemampuan, keahlian atau tenaga yang dimilikinya untuk kepentingan majikannya atau pemberi kerja contohnya seperti orang perseorangan, pengusaha, badan hukum, atau badan-badan lainnya. Hal ini sesuai dengan Pasal 1 angka 2 UndangUndangNomor 13 Tahun 2003 Tentang Ketenagakerjaan (UU Ketenagakerjaan) bahwa tenaga kerja adalah setiap orang yang mampu melakukan suatu pekerjaan agar menghasilkan barang dan/atau jasa baik untuk memenuhi kebutuhan sendiri maupun untuk masyarakat. ${ }^{2}$

Pada Tanggal 31 Desember Tahun 2019 di Wuhan, China pertama kali terjadi kasus pneumonia yang dilaporkan kepada World Health Organization (WHO). China mengumumkan bahwa kasus pneumonia yang tidak diketahuii di Wuhan bukanlah SARS atau MERS. Pada 7 Januari 2020 pihak berwenang China mengkonfirmasi

\footnotetext{
1 Lanny Ramli, Hukum Ketenagakerjaan (Airlangga University Press 2008).[1].

2 Pasal 1 angka 2 Undang-Undang Nomor 13 Tahun 2003 Tentang Ketenagakerjaan.
} 
bahwa mereka telah mengidentifikasi virus tersebut sebagai virus corona baru dan oleh WHO penyakit akibat virus corona tersebut diberi nama sebagai Corona Virus Disease 2019 yang selanjutanya disebut COVID-19. Tanggal 2 Maret 2020 Pemerintah Indonesia secara resmi mengumumkan dua WNI positif COVID-19 dan hal tersebut merupakan kasus pertama COVID-19 di Indonesia. Tidak hanya menyebar ke negara Indonesia tetapi penyakit ini juga menyebar ke berbagai negara di seluruh dunia, sehingga pada tanggal 11 Maret 2020 WHO menyatakan bahwa wabah COVID-19 sebagai pandemi. ${ }^{3}$

Pemerintah Indonesia mengeluarkan kebijakan untuk memutus rantai penyebaran COVID-19 seperti melarang turis asing masuk ke Indonesia, larangan untuk mudik pada tahun 2020 dan yang paling utama adalah metode Pembatasan Sosial Berskala Besar yang selanjutnya disebut PSBB yang didalamnya terkandung konsep social dan physical distancing. Metode PSBB ditetapkan melalui Peraturan Pemerintah Nomor 21 Tahun 2020 Tentang Pembatasan Sosial Berskala Besar dalam Rangka Percepatan Penanganan Corona Virus Disease 2019 (COVID-19) (PP Nomor 21 Tahun 2020 Tentang PSBB dalam Rangka Percepatan Percepatan Penanganan COVID-19).

Dalam kebijakan PSBB terkandung konsep bekerja dari rumah atau yang disebut Work Frome Home. Work From Home (WFH) adalah sebuah konsep kerja atau sistem kerja dimana pekerja dapat melakukan pekerjaannya dari rumah ataupun tempat lain diluar dari tempat bekerja. Dengan penerapan konsep kerja Work From Home terdapat beberapa aspek yang berbeda saat pekerja melakukan pekerjaanya dilingkungan kerja, terutama mengenai perlindungan pekerja dalam hal terjadinya kecelakaan kerja. Berdasarkan Pasal 1 angka 1 Peraturan Pemerintah Nomor 44 Tahun 2015 Tentang Penyelenggaraan Program Jaminan Kecelakaan Kerja dan Jaminan Kematian (PP Nomor 44 Tahun 2015 Tentang Penyelenggaraan Program JKK dan JKM) menyatakan bahwa:

3 Mela Arnani, 'Timeline Wabah Virus Corona, Terdeteksi pada Desember 2019 hingga jadi Pandemi Global'(Kompas 2020) < https://www.kompas.com> accessed 23 Mei 2020. 
"Jaminan Kecelakaan Kerja yang selanjutnya disingkaat JKK adalah manfaat berupa uang tunai dan/atau pelayanan kesehatan yang diberikan pada saat peserta mengalami kecelakaan kerja atau penyakit yang disebabkan oleh lingkungan kerja."

Sedangkan rumah yang menjadi tempat bagi pekerja yang bekerja dengan sistem Work From Home selama berlakunya PSBB bukanlah termasuk lingkungan kerja. Hal ini diperkuat dengan definisi lingkungan kerja yang diatur dalam Pasal 1 angka 5 Permenaker Nomor 5 Tahun 2018 Tentang K3 Lingkungan Kerja yang menyatakan bahwa:

"Lingkungan Kerja adalah aspek Higiene di Tempat Kerja yang di dalamnya mencakup faktor fisika, kimia, biologi, ergonomi dan psikologi yang keberadaannya di Tempat Kerja dapat mempengaruhi keselamatan dan kesehatan Tenaga Kerja".

Sedangkan ancaman terjadinya kecelakaan kerja bisa terjadi dimana-mana termasuk didalam rumah/tempat tinggal, secara yuridis pekerja mempunyai hak untuk memperoleh perlindungan atas keselamatan dan kesehatan kerja sesuai Pasal 86 ayat (1) huruf a UU Ketenagakerjaan.

\section{Konsep Work From Home}

Sistem Work From Home (WFH) atau bekerja dari rumah termasuk bagian dari konsep telecommuting atau bekerja jarak jauh. ${ }^{4}$ Pengertian bekerja jarak jauh menurut Huuhtanen (1997) yaitu pekerjaan yang dilakukan oleh seseorang (pegawai, pekerja mandiri, pekerja rumahan) secara khusus, atau hanya waktu tertentu, pada sebuah lokasi jauh dari kantor, menggunakan media telekomunikasi sebagai alat kerja. ${ }^{5}$ Definisi secara yuridis Work From Home (WFH) belum diatur dalam peraturan perundang-undangan namun sistem ini telah digunakan oleh Indonesia sejak masuknya pandemi COVID-19 wilayah Indonesia. Sistem bekerja Work From Home digunakan Provinsi Jawa Timur berdasarkan Peraturan Gubernur

4 Oswar Mungkasa, 'Bekerja dari Rumah (Working From Home/WFH): Menuju Tatanan Baru Era Pandemi COVID 19’ (2020) Volume. IV No.2 The Indonesian Journal of Development Planning.[1].

5 ibid.[4]. 
Jawa Timur Nomor 18 Tahun 2020 Tentang Pedoman Pembatasan Sosial Berskala Besar dalam Penanganan Corona Virus Disease 2019 (COVID-19) Di Provinsi Jawa Timur dalam Pasal 9 yang menyatakan:

(1) Selama pemberlakuan PSBB, dilakukan penghentian sementara kegiatan bekerja di tempat kerja/kantor;

(2) Selama penghentian sementara kegiatan bekerja di tempat kerja/kantor sebagaimana dimaksud pada ayat (1), harus mengganti kegiatan bekerja di tempat kerja dengan kegiatan bekerja di rumah/tempat tinggal;

(3) Selama penghentian sementara kegiatan bekerja di tempat kerja/kantor sebagaimana dimaksud pada ayat (1), harus tetap menugaskan karyawan atau petugas keamanan untuk menjaga tempat kerja/kantor.

Tepatnya Pasal 9 ayat (2) Peraturan tersebut tertuang kebijakan penerapan konsep Work From Home di Provinisi Jawa Timur, selain itu melalui Pasal 9 ayat 3 Peraturan tersebut kita menyadari bahwa tidak semua jenis pekerjaan bisa diterapkan sistem Work From Home contohnya seperti petugas keamanan atau satpam yang mau tidak mau harus menjaga tempat kerja/tempat kantor karena tugas untuk menjaga tidak bisa dilakukan di rumah atau tempat tinggalnya, berbeda dengan pekerjaan yang menyangkut administrasi, keuangan, desain, apapun yang memang bisa pekerjaan tersebut dikerjakan di rumah.

\section{Kecelakaan Kerja Pekerja Work Frome Home}

Kehidupan manusia tidak lepas akan potensi atau ancaman terjadinya kecelakaan. Kecelakaan adalah sebuah kejadian tak terduga yang menyebabkan cedera dan/atau kerusakan. ${ }^{6}$ Kecelakaan merupakan peristiwa atau kejadian yang tidak direncanakan, tidak diharapkan, dan tidak diduga oleh kita manusia yang terjadi secara tidak ada unsur kesengajaan beserta dampak buruk yang dialami akibat kecelakaan. Dalam kehidupan bekerjapun terdapat potensi terjadinya kecelakaan dan hal tersebut biasa disebut kecelakaan kerja.

6 John Ridley, Ikhtisar Kesehatan dan Keselamatan Kerja, Edisi Ketiga (terjemahan Soni Astranto) (Penerbit Erlangga 2008).[113]. 
Potensi terjadinya kategori kecelakaan kerja yaitu penyakit yang disebabkan oleh lingkungan kerja atau penyakit akibat kerja terhadap pekerja Work From Home sebagai berikut:

1. Work-Related Stress

Dilansir dari Health and Safety Executive UK, bahwa Work From Home dapat mengakibatkan gangguan pada kesehatan mental pekerja atau Work-Related Stress. ${ }^{7}$ Hal ini tidak lepas akan faktor lone working atau bekerja sendirian yang dialami oleh pekerja Work From Home.

2. Dampak Buruk Tidak Ergonomi

Secara umum Ergonomi diartikan sebagai ilmu yang mempelajari hubungan antara pekerja dan lingkungan kerjanya untuk penyesuaian yang optimal dinyatakan dalam efisiensi kerja, kesehatan, dan kesejahteraan. ${ }^{8}$ Pemahaman lain tentang Ergonomi adalah ilmu mendesain pekerjaan, peralatan, dan tempat kerja sesuai dengan pekerja. ${ }^{9}$ Tujuan ergonomi secara umum yaitu pertama, meningkatkan produktivitas dan kenyamanan. Kedua, meningkatkan kesejahteraan fisik, psikis, dan sosial. Ketiga, mencegah tekanan kerja dan kelelahan. Keempat, menjaga keseimbangan antara sistem kerja manusia dengan mesin atau peralatan bekerja. Selain itu terdapat tujuan utama ergonomi adalah untuk pencegahan potensi terjadinya kecelakaan kerja. ${ }^{10}$ Contoh risiko bilamana tidak ergonomi yaitu cedera pada bagian tubuh, tidak bisa disangkal dalam setiap aktivitas bekerja apapun bentuknya pasti terdapat potensi mengalami cedera seperti menarik, mendorong, mengangkat, dan menggengam (jumlah banyak gerakan yang diulang), postur tubuh pekerja apabila kepala dan leher pekerja membungkuk ke depan, ke belakang, atau ke samping dalam waktu yang lama.

\footnotetext{
7 Avinia Ismiyati, 'Pengendalian Bahaya dan Risiko K3 Saat WFH', (kumparan,2020) $<$ kumparan.com $>$ accessed 2 November 2020.

8 Indah Rachmatiah Siti Salami,[et al.], Kesehatan dan Keselamatan Lingkungan Kerja (Gadjah Mada University 2019).[204].

9 Febri Endra Budi Setyawan, 'Penerapan Ergonomi Dalam Konsep Kesehatan' (2011) Volume 7 Saintika Medika: Jurnal Ilmu Kesehatan dan Kedokteran Keluarga.[39].

10 ibid.[40].
} 
Pekerja dalam keadaan Work From Home berpotensi tidak ergonomi saat bekerja. hal ini dikarenakan ruang kerja dan peralatan atau properti kerja yang ada di rumah berbeda standart yang sesuai ergonomi dengan yang ada di tempat kerja bahkan tidak menutup kemungkinan pekerja dalam keadaan Work From Home bekerja dengan keadaan seadanya dengan keadaan waktu yang cukup lama. Contohnya yaitu Pertama, bekerja dengan tidak menggunakan kursi yang nyaman seperti di tempat kerja melainkan hanya duduk beralaskan lantai rumah sehingga lebih cepat merasakan sakit pada bagian tulang ekor pekerja. Kedua, bekerja tidak menggunakan meja kerja dengan ketinggian yang sesuai dengan ergonomi seperti meja di tempat kerja melainkan menggunakan meja yang seadanya di rumah apabila meja yang terdapat di rumah lebih pendek maka postur tubuh pekerja lebih membungkuk. Hal ini mempengaruhi postur tubuh pekerja yang berakibat cepat lelah, berpotensi mengalami cedera pada tubuh (tulang punggung), berpotensi mengalami gangguan otot rangka atau disebut musculoskeletal disorders. Ketiga, kualitas pencahayaan di rumah berbeda dengan kualitas pencahayaan di tempat kerja, karena jika dibandingkan dengan di tempat kerja sudah pasti telah dirancang sesuai ergonomic. Hal ini berpotensi akan berdampak pada kesehatan mata pekerja seperti kelelahan mata (eye fatigue) dan mata rabun jauh.

\section{Perlindungan K3 Pekerja Work From Home}

Kegiatan bekerja yang dilaksanakan oleh pekerja tidak lepas akan risiko terjadinya kecelakaan kerja dari pekerjaannya sehingga suatu keniscayaan bahwa perlindungan K3 adalah sesuatu hal yang diutamakan dalam bekerja. Keselamatan dan kesehatan kerja berhubungan erat dengan kecelakaan kerja dikarenakan apabila Keselamatan dankesehatan di tempatkerjabagus maka peluang terjadinyakecelakaan kerja di tempat kerja akan semakin kecil. Ditinjau dari segi keilmuan Keselamatan dan kesehatan kerja diartikan sebagai ilmu pengetahuan dan penerapannya dalam usaha mencegah kemungkinan terjadinya kecelakaan kerja di tempat kerja. ${ }^{11} \mathrm{~K} 3$

${ }^{11}$ Sendjun H. Manulang, Pokok-Pokok Hukum Ketenagakerjaan Di Indonesia (PT. Rineka Cipta 2001).[83]. 
merupakan masalah yang terdapat banyak aspek didalamnya misalnya hukum, ekonomi dan sosial. ${ }^{12}$ Berdasarkan Pasal 1 angka 2 Peraturan Pemerintah Nomor 50 Tahun 2012 Tentang Penerapan Sistem Manajemen Keselamatan dan Kesehatan Kerja menyatakan bahwa: "Keselamatan dan Kesehatan Kerja adalah segala kegiatan untuk menjamin dan melindungi keselamatan dan kesehatan tenaga kerja melalui upaya pencegahan kecelakaan kerja dan penyakit akibat kerja”.

Hal ini tidak lepas akan hak pekerja yang telah diatur dalam Pasal 86 ayat (1) huruf a UU Ketenagakerjaan yang menyatakan bahwa setiap pekerja mempunyai hak untuk memperoleh perlindungan atas keselamatan dan kesehatan kerja. perlindungan keselamatan dan kesehatan kerja tidak hanya penting bagi pihak pekerja namun juga merupakan hal yang penting bagi pihak pemberi kerja karena dampak kecelakaan kecelakaan kerja baik secara langsung maupun tidak langsung juga merugikan bagi pihak pemberi kerja. Tujuan dari perlindungan keselamatan dan kesehatan kerja adalah: ${ }^{13}$

1. Mewujudkan lingkungan kerja yang aman, sehat dan sejahtera;

2. Mewujudkan produktivitas kerja yang optimal;

3. Mencegah terjadinya kecelakaan kerja.

Dalam pelaksanaan perlindungan K3 di tempat kerja dilaksanakan secara bersama-sama oleh pemberi kerja dan seluruh tenaga kerja. ${ }^{14}$ Karena tanpa kerjasama dengan seluruh tenaga kerja akan sulit dalam pelaksanaannya, disisi lain perlindungan K3 tidak lepas dengan intervensi pihak pemerintah dengan pembentukan payung hukum berkaitan dengan Keselamatan dan Kesehatan Kerja terdapat peran pihak pemerintah dengan hadirnya Badan Penyelenggaran Jaminan Sosial Ketenagakerjaan yang selanjutnya disebut BPJS Ketenagakerjaan sebagai perwujudan perlindungan keselamatan dan kesehatan kerja terutama kaitannya dengan kecelakaan kerja melalui program jaminan sosial yaitu Jaminan Kecelakaan Kerja.

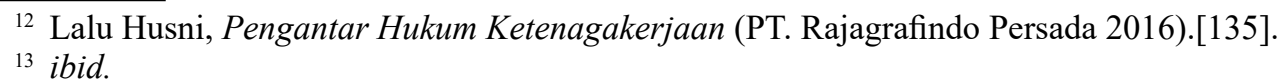

13 ibid. 


\section{Tanggung Jawab Pemberi Kerja Terkait K3 Work From Home}

Pemberi kerja bertanggung jawab atas perlindungan keselamatan dan Kesehatan Pekerja Work From Home dengan menerapkan Sistem Manajemen K3 yang selanjutnya disebut SMK3. Hal ini merupakan upaya pencegahan (preventif) agar tidak terjadi kecelakaan kerja di tempat kerja. Tanggung jawab pemberi kerja tersebut diatur dengan jelas dalam Pasal 87 UU Ketenagakerjaan yang menyatakan bahwa: "Setiap perusahaan wajib menerapkan sistem manajemen keselamatan dan kesehatan kerja yang terintegrasi dengan sistem manajemen perusahaan".

Pasal 86 UU Ketenagakerjaan mengatur tentang kewajiban bagi pemberi kerja untuk memberikan perlindungan keselamatan kerja. Sebagaimana dimaksud dalam Pasal 5 Peraturan Pemerintah Nomor 50 Tahun 2012 Tentang Penerapan Sistem Manajemen Keselamatan dan Kesehatan Kerja (PP Nomor 50 Tahun 2012 Tentang Penerapan SMK3) ditegaskan bahwa setiap perusahaan yang mempekerjakan pekerja paling sedikit 100 (seratus) orang atau mempunyai tingkat potensi bahaya tinggi yang dapat mengakibatkan kecelekaan kerja dengan dampak merugikan jiwa manusia wajib menerapkan SMK3 di tempat kerja. Berdasarkan sub-bab 2.2 dalam penulisan ini bahwa dengan menggunakan penafsiran gramatikal dan penafsiran ekstensif bahwa rumah dalam keadaan Work From Home yang terdapat potensi terjadinya kecelakaan kerja terhadap pekerja yang bekerja dalam keadaaan Work Frome Home maka perlu adanya SMK3 sebagai tanggung jawab pemberi kerja.

Sistem Manajemen Keselamatan dan Kesehatan Kerja (SMK3) diatur dalam PP Nomor 50 Tahun 2012 Tentang Penerapan SMK3. berdasarkan Pasal 1 Peraturan tersebut menyatakan bahwa:

"Sistem Manajemen Keselamatan dan Kesehatan Kerja yang selanjutnya disingkat SMK3 adalah bagian dari sistem manajemen perusahaan secara keseluruhan dalam rangka pengendalian risiko yang berkaitan dengan kegiatan kerja guna terciptanya tempat kerja yang aman, efisien dan produktif". 
Tujuan dari penerapan SMK3 untuk: ${ }^{15}$

a. Mencegah terjadinya kecelakaan kerja;

b. Sebagai alat untuk mencapat derajat kesehatan dan gizi para pekerja yang setinggi-tingginya;

c. Menciptakan kondisi tempat kerja yang aman dan nyaman;

d. Mendorong produktivitas pekerja;

e. Meningkatkan efektifitas perlindungan keselamatan dan kesehatan kerja yang terencana, terukur, terstruktur, dan terintegrasi;

f. memberantas kelelahan kerja dan meningkatkan gairah serta kenikmatan bekerja.

Terdapat beberapa tahapan yang wajib dilakukan oleh pemberi kerja dalam menerapkan SMK3 bagi pekerja dalam keadaan Work From Home sebagaimana diatur dalam PP Nomor 50 Tahun 2012 Tentang Penerapan SMK3 adalah sebagai berikut: ${ }^{16}$
a. Menetapkan kebijakan K3;
b. Melakukan perencanaan K3;
c. Melaksanakan rencana K3;
d. Memantau dan melakukan evaluasi kinerja K3; dan
e. Meninjau dan meningkatkan kinerja SMK3.

Pertama, Pasal 7 hingga Pasal 8 PP Nomor 50 Tahun 2012 Tentang Penerapan SMK3 mengatur perihal penetepan kebijakan K3 oleh pemberi kerja. dalam membuat kebijakan K3 pekerja yang bekerja dalam keadaan Work Frome Home, pemberi kerja wajib melakukan tinjuan awal kondisi K3 yang tepat sesuai kondisi masing-masing pekerja yang dalam keadaan Work Frome Home, memperhatikan peningkatan kinerja manajemen K3, dan memperhatikan masukan dari pekerja dan/ atau serikat pekerja. Tinjauan awal kondisi K3 yang dimaksud meliputi:

1. Pengidentifikasi potensi bahaya, penilaian dan pengendalian risiko;

2. Perbandingan penerapan $\mathrm{K} 3$ dengan perusahaan dan bidang lain yang lebih baik;

3. Peninjauan sebab akibat kejadian yang membahayakan;

4. Kompensasi dan gangguan serta hasil penilaian sebelumnya yang berkaitan dengan keselamatan; dan

5. Penilaian efisiensi dan efektivitas sumber daya yang disediakan.

\footnotetext{
${ }^{15}$ Rudi Suardi, Sistem Manajemen Keselamatan dan Kesehatan Kerja, (Lembaga Manajemen PPM dan Penerbit PPM 2018).[3].

${ }^{16}$ Pasal 6 Peraturan Pemerintah Nomor 50 Tahun 2012 Tentang Penerapan Sistem Manajemen Keselamatan dan Kesehatan Kerja.
} 


\section{Tanggung Jawab BPJS Terkait Jaminan Kecelakaan Kerja Pekerja Work From Home}

Pekerja juga manusia yang haknya dilindungi UUD NRI 1945. Pasal 28 UUD NRI 1945 mengatur bahwa setiap orang berhak hidup sehat dan sejahtera, dan berhak memperoleh pelayanan kesehatan termasuk jaminan sosial yang merupakan salah satu bentuk perlindungan sosial. ${ }^{17}$ Oleh karena itu Pemerintah Indonesia berkewajiban untuk mengembangkan sistem jaminan sosial bagi seluruh rakyat Indonesia. Berdasarkan Pasal 18 Undang-Undang Nomor 40 Tahun 2004 Tentang Sistem Jaminan Sosial Nasional (UU SJSN) mengatur bahwa terdapat macammacam program jaminan sosial yang meliputi:
a. Jaminan Kesehatan;
b. Jaminan Kecelakaan Kerja;
c. Jaminan Kematian;
d. Jaminan Pensiun; dan
e. Jaminan Hari Tua.

Untuk mewujudkan terselenggaranya sistem jaminan sosial dibentuklah badan penyelenggara yang berbentuk badan hukum dengan Undang-Undang. Oleh karena itu Pemerintah Indonesia membentuk Badan Penyelenggara Jaminan Sosial yang selanjutnya disebut BPJS melalui Undang-Undang Nomor 24 Tahun 2011 Tentang Badan Penyelenggara Jaminan Sosial (UU BPJS). Terdapat 2 jenis BPJS yang berbeda yaitu BPJS Kesehatan yang menyelenggarakan program jaminan kesehatan dan BPJS Ketenagakerjaan yang menyelenggarakan jaminan kecelakaan kerja, jaminan kematian, jaminan pension, dan jaminan hari tua. ${ }^{18}$ Berdasarkan UU SJSN dan Peraturan Pemerintah Nomor 84 Tahun 2013 Tentang Perubahan Kesembilan Atas Peraturan Pemerintah Nomor 14 Tahun 1993 Tentang Penyelenggaraan Program Jaminan Sosial Tenaga Kerja (PP Nomor 84 Tahun 2014 Tentang Perubahan Kesembilan atas PP Nomor 14 Tahun 1993 Tentang Penyelenggaraan Program Jaminan Sosial Tenaga Kerja) karena pada prinsipnya pemberi kerja memiliki kewajiban untuk mendaftarkan pekerjanya bahkan dirinya

\footnotetext{
${ }_{17}$ Pasal 28 Undang-Undang Negara Republik Indonesia 1945.

18 Pasal 6 Undang-Undang Nomor 24 Tahun 2011 Tentang Badan Penyelenggara Jaminan Sosial.
} 
sebagai peserta program Jaminan Kecelakaan Kerja kepada BPJS Ketenagarkerjaan sebagai upaya perlindungan keselamatan dan kesehatan pekerja.

Dalam penulisan ini, penulis menetapkan bahwa pekerja dalam keadaan Work From Home merupakan peserta program JKK BPJS Ketenagakerjaan. Oleh karena itu apabila pekerja dalam keadaan Work From Home mengalami kecelakaan kerja maka BPJS Ketenagakerjaan bertanggung jawab untuk memberikan manfaat program JKK kepada pekerja tersebut yang meliputi: ${ }^{19}$

1. Pelayanan kesehatan sesuai kebutuhan medis akibat dampak kecelakaan kerja yang meliputi:
a. Pemeriksaan dasar dan penunjang;
b. Perawatan tingkat pertama dan lanjutan;
c. Rawat inap kelas I rumah sakit pemerintah, rumah sakit pemerintah daerah, atau rumah sakit swasta yang setara;
d. Perawatan intensif;
e. Penunjang diagnostik;
f. Penanganan;
g. Pelayanan khusus;
h. Alat kesehatan dan implan;
i. Jasa dokter/medis;
j. Operasi;
k. Pelayanan darah;
1. Rehabilitasi medik;
m. Perawatan di rumah bagi Peserta yang tidak dimungkinkan melanjutkan pengobatan ke rumah sakit; dan
n. Pemeriksaan diagnostic dalam penyelesaian kasus penyakit akibat kerja.

2. Santunan berupa uang yang meliputi

a. Penggantian biaya transportasi bagi:

1. Peserta yang mengalami kecelakaan kerja, menuju rumah sakit dan/ atau ke rumahnya, pertolongan pertama pada kecelakaan, dan rujukan ke rumah sakit lain;

2. Peserta yang mengikuti program kembali kerja menuju dan pulang dari fasilitas kesehatan dan balai latihan kerja.

b. Santunan sementara tidak mampu bekerja;

c. Santunan cacat sebagian anatomis, cacat sebagian fungsi, dan cacat total tetap;

d. Santunan kematian dan biaya pemakaman;

e. Santunan berkala yang dibayarkan sekaligus apabila meninggal dunia atau Cacat total tetap akibat kecelakaan kerja;

19 Pasal 25 Peraturan Pemerintah Nomor 84 Tahun 2014 Tentang Perubahan Kesembilan atas Peraturan Pemerintah Nomor 14 Tahun 1993 Tentang Penyelenggaraan Program Jaminan Sosial Tenaga Kerja. 
f. Biaya rehabilitasi berupa penggantian alat bantu (orthose) dan/atau alat pengganti (prothese);

g. Penggantian biaya gigi tiruan, kacamata, dan alat bantu dengar; dan/atau

h. Beasiswa pendidikan bagi 2 anak bagi setiap Peserta yang meninggal dunia atau Cacat total tetap akibat kecelakaan kerja sesuai dengan tingkat Pendidikan anak Peserta tersebut.

\section{Kesimpulan}

Rumah dalam keadaan Work From Home termasuk lingkungan kerja. Berdasarka penafsiran gramatikal dan ekstensif rumah dalam keadaan Work From Home termasuk tempat kerja yang didalamnya terdapat unsur-unsur lingkungan kerja yang diatur dalam Pasal 1 angka 5 Permenaker Nomor 5 Tahun 2018 Tentang K3 Lingkungan Kerja yaitu unsur aspek hygiene, tempat kerja, faktor fisika, faktor kimia, faktor biologi, faktor ergonomi, faktor psikologi, dan mempengaruhi keselamatan dan kesehatan pekerja.

Terdapat 2 pihak yang bertanggungjawab atas kecelakaan kerja terhadap pekerja yang bekerja dengan sistem bekerja dari rumah (Work From Home) yaitu pemberi kerja dan BPJS Ketenagakerjaan. Upaya pencegahan terjadinya kecelakaan kerja dengan adanya perlindungan keselamatan dan kesehatan kerja berupa penerapan SMK3 di lingkungan kerja termasuk mendaftarkan pekerjanya sebagai peserta program Jaminan Kecelakaan Kerja BPJS Ketenagakerjaan sebagai bentuk tanggungjawab perlindungan akibat kecelakaan kerja oleh pemberi kerja dan BPJS Ketenagakerjaan bertangungjawab atas pemenuhan manfaat dari program JKK kepada pekerja yang dalam keadaan Work From Home sebagai peserta yang mengalami kecelakaan kerja.

\section{Daftar Bacaan}

\section{Buku}

Lalu Husni, Pengantar Hukum Ketenagakerjaan (PT. Rajagrafindo Persada, 2016).

Sendjun H. Manulang, Pokok-Pokok Hukum Ketenagakerjaan Di Indonesia (PT. Rineka Cipta 2001). 
Lanny Ramli, Hukum Ketenagakerjaan (Airlangga University Press 2008).

John Ridley, Ikhtisar Kesehatan dan Keselamatan Kerja Edisi Ketiga, (terjemahan Soni Astranto) (Penerbit Erlangga 2008).

Indah Racmatiah Siti Salami, [et al.] Kesehatan dan Keselamatan Lingkungan Kerja (Gadjah Mada University Press 2019).

Rudi Suardi, Sistem Manajemen Keselamatan dan Kesehatan Kerja (Lembaga Manajemen PPM dan Penerbit PPM 2018).

\section{Jurnal}

Oswar Mungkasa, 'Bekerja dari Rumah (Working From Home/WFH): Menuju Tatanan Baru Era Pandemi COVID 19' (2020) IV No.2 The Indonesian Journal of Development Planning.

Febri Endra Budi Setyawan, 'Penerapan Ergonomi Dalam Konsep Kesehatan' (2011) 7 Saintika Medika: Jurnal Ilmu Kesehatan dan Kedokteran Keluarga.

\section{Laman}

Avinia Ismiyati, 'Pengendalian Bahaya dan Risiko K3 Saat WFH' (kumparan,2020) $<$ kumparan.com $>$.

Mela Arnani, 'Timeline Wabah Virus Corona, Terdeteksi pada Desember 2019 hingga jadi Pandemi Global' (Kompas,2020) https://www.kompas.com.

\section{Perundang-undangan}

Undang-Undang Dasar Negara Republik Indonesia Tahun 1945.

Undang-Undang Nomor 13 Tahun 2003 tentang Ketenagakerjaan (Lembaran Negara Republik Indonesia Tahun 2003 Nomor 39, Tambahan Lembaran Negara Nomor 4279).

Undang-Undang Nomor 40 Tahun 2004 Tentang Sistem Jaminan Sosial Nasional (Lembaran Negara Republik Indonesia Tahun 2004 Nomor 150, Tambahan Lembaran Negara Nomor 4456).

Undang-Undang Nomor 24 Tahun 2011 Tentang Badan Penyelenggara Jaminan Sosial (Lembaran Negara Republik Indonesia Tahun 2011 Nomor 116, Tambahan Lembaran Negara Nomor 5256).

Peraturan Pemerintah Nomor 50 Tahun 2012 Tentang Penerapan Sistem Manajemen 
Keselamatan dan Kesehatan Kerja (Lembaran Negara Republik Indonesia Tahun 2012 Nomor 100, Tambahan Lembaran Negara Nomor 5309).

Peraturan Pemerintah Nomor 84 Tahun 2013 Tentang Perubahan Kesembilan Atas Peraturan Pemerintah Nomor 14 Tahun 1993 Tentang Penyelenggaraan Program Jaminan Sosisl Tenaga Kerja (Lembaran Negara Republik Indonesia Tahun 2013 Nomor 229, Tambahan Lembaran Negara Nomor 5472).

Peraturan Pemerintah Nomor 44 Tahun 2015 Tentang Penyelenggaraan Program Jaminan Kecelakaan Kerja dan Jaminan Kematian. (Lembaran Negara Republik Indonesia Tahun 2015 Nomor 154, Tambahan Lembaran Negara Nomor 5714).

Peraturan Pemerintah Nomor 21 Tahun 2020 Tentang Pembatasan Sosial Berskala Besar dalam Rangka Percepatan Penanganan Corona Virus Disease 2019 (COVID-19). (Lembaran Negara Republik Indonesia Tahun 2020 Nomor 91, Tambahan Lembaran Negara Nomor 6487).

Peraturan Menteri Ketenagakerjaan Nomor 5 Tahun 2018 Tentang Keselamatan dan Kesehatan Kerja Lingkungan Kerja. (Lembaran Negara Republik Indonesia Tahun 2013 Nomor 229, Tambahan Lembaran Negara Nomor 5472).

Peraturan Gubernur Jawa Timur Nomor 18 Tahun 2020 Tentang Pedoman Pembatasan Sosial Berskala Besar dalam Penanganan Corona Virus Disease 2019 (COVID-19) Di Provinsi Jawa Timur. 
Valerieo Ezra: Kecelakaan Kerja yang...

--halaman ini sengaja dibiarkan kosong-- 